\title{
A STUDY OF SUBCHRONIC GENOTOXIC EFFECTS OF ZINC OXIDE NANOPARTICLES AND PROTECTIVE ROLE OF VITAMIN E ON THE STOMACH AND PANCREAS IN ADULT ALBINO RATS
}

\author{
Eman A.A. Abdallah"1, Mai M. Abdelwahab ${ }^{2}$, and Bothina H.F. Omran ${ }^{3}$ \\ ${ }^{1,3}$ Departments of Forensic Medicine and Clinical Toxicology \\ ${ }^{2}$ Departments of pathology, Faculty of Medicine, Zagazig University. Alsharqia, Egypt.
}

\begin{abstract}
Background: Nanoparticles (NPs) are used in a wide range in different fields for example cosmetics, manufacturing of clothing, personal care products, and sun protective creams. Diagnosis, imaging, and drug delivery are also considered very important fields using nanoparticles. Zinc oxide $(\mathrm{ZnO})$ NPs is considered one of the greatest frequently used nanoparticles. As $\mathrm{ZnO}$ NPs are the furthermost consumed nanomaterials in numerous user products, various scientific works have shown the toxic hazards of $\mathrm{ZnO}$ NPs in numerous body systems. Aim: The aim of this work was to detect some of the toxic effects of Zinc oxide nanoparticles and also, to elucidate the protective role of vitamin $\mathrm{E}$ (vit E) on stomach and pancreatic cells of adult male albino rats. Material and methods: Zinc oxide ( $\mathrm{ZnO}) \mathrm{NPs}$ was administrated orally at dose of (422 mg/kg body weight) (1/20 LD 50) daily for 8 weeks. Serum levels of glutathione and malondialdehyde (MDA) were estimated. Stomach and Pancreas histopathological microscopic examinations were accomplished. Detection of DNA fragmentation was performed. Results: The results after being statistically analyzed and tabulated revealed that oral Zinc oxide nanoparticles administration induced a significant decrease in serum glutathione and significant increase in serum MDA. It also induced severe histopathological alterations in stomach and pancreatic cells with DNA fragmentation. Administration of vitamin $\mathrm{E}$ in addition to zinc oxide NPs induced a significant increase in serum glutathione and a significant decrease in serum MDA, also stomach and pancreatic cells showed mild histopathological changes. Also, vitamin E administration suppressed apoptosis and DNA fragmentation. Conclusion: It was concluded that oral zinc oxide nanoparticles administration induced oxidative stress and destructive genotoxic effects in the stomach and pancreatic cells, and vitamin E administration during exposure to zinc oxide nanoparticles may offer protection against their damaging effect. Recommendations: Zinc oxide nanoparticles caused a potential risk for a series of crucial damage, so zinc oxide nanoparticles exposure either occupationally or dietary must be restricted. Also, raising the awareness among population about its hazardous effects and at the same time, about the potential beneficial effect of vitamin E administration.
\end{abstract}

KEYWORDS: Zinc oxide nanoparticles, Oxidative stress, Vitamin E, Stomach, Pancreatic cells, DNA fragmentation 


\section{INTRODUCTION}

Nanotechnology, one of the greatest prospective technologies of $21^{\text {st }}$ century, broadly has been used in wide range worldwide. Electronics production, clothes manufacturing, products of skin care and health care materials such as antimicrobial agents and drug distribution are having nanoparticle compounds in a different extent (Jeong et al., 2013).

Nanoparticles are very small components with one dimension sized from 1 to 100 nanometers. When comparing it to other particles found in micro scale, nanomaterials have largespecific surface area, so display altered grades of biological properties (Esmaeillou et al., 2013).

Zinc oxide $(\mathrm{ZnO})$ nanoparticles (NPs) are broadly used in synthesis of rubbery materials, paint product, metals, wave filters, UV rays detectors, solar cell system, sensors, drug carriers, and sunscreen for protection of ultraviolet (UV)-rays which induce skin injury. Zinc oxide nanoparticles can scatter UV radiation and offer skin protection to some extent (Rasmussen et al., 2010).

Workers dealing with zinc oxide nanoparticles are exposed to toxicity of these nanomaterials by hand to mouth exposure. Food chain also plays as a rout of zinc oxide nanomaterials inoculation from environment into the human body (Sharma et al., 2012).

Even so inhalable particles of zinc oxide nanoparticles, can reach the gastrointestinal tract when mucociliary mechanism of lung expel these particles backwards to be swallowed. ZnO NPs pass from the lumen of the gastrointestinal tract to blood circulating all over the body and embedded into various organs (Chang et al., 2012).

Zinc oxide nanoparticle easy to be removed from inoculation site because of its small size, the residue circulates for long time pass slowly to the interstitial spaces than the larger ones (Almansour et al., 2017).

It is expectable that the venture of $\mathrm{ZnO}$ NPs will increase and human will be more affected by these nanomaterials via different routes of exposure such as inhalation, ingestion and also via dermal which considered the weakest route of exposure. Zinc oxide NPs show great accumulation particularly in vital organs after it was taken into the circulatory system (Lanone and Boczkowski, 2006).

According to two factors: material composition and surface characteristics; zinc oxide nanoparticles produce ROS spontaneously. Toxicity of $\mathrm{ZnO}$ NPs occurs when there is a defect in the balance between ROS production and cellular antioxidant defense system where ROS is highly elevated going beyond the capacity of the defense system, that cause cells to enter a state of oxidative stress, resulting in damage of cellular structures (Premanathan et al., 2011).

Oxidative stress induced by $\mathrm{ZnO}$ nanoparticles toxicity generates free radicals and these free radicals cause tissues destruction, peroxidation of lipid, leakage through cell membrane, oxidative damage of DNA, intracellular calcium essentially increased, and even anti-proliferative activity, all are encouraged by $\mathrm{ZnO}$ nanoparticles in diverse cell lines. Even so exposure to 
sub-lethal concentration of $\mathrm{ZnO}$ nanoparticles encourages some genes expression that is responsible for apoptosis and oxidative stress (Sharma et al., 2012).

Inflammatory response, genotoxicity, and tissue damages are all considered the end- result of nanoparticles toxicity. $\mathrm{ZnO}$ NP-can induce oxidative DNA damage by stimulating autophagy pathways, which disturb the balance between cell existence and cytotoxicity (Scherzad et al., 2017).

Kononenko et al. (2017), stated that there was a difference between chemically stable metallic nanoparticles and nanoparticles that have the ability to be oxidized, reduced, or dissolved. The later has both cytotoxic and genotoxic effects. A fall of both glutathione $\mathrm{S}$ transferase and catalase activity is followed by damage of DNA and chromosome.

The toxicity of NPs depends on the physicochemical characters of these NPs, including the following: nanoparticles size, form, surface area, and surface charge. Two of these factors are very important during exposure by inhalation, mass and surface area of NPs. These results recommend that particle size and dose metrics are major factors of nanotoxicology and important to be considered while assessing the toxicity of different synthesized NPs. The surface charge (especially ligands) also considered precarious factor for nanotoxicity, which alters their surface and affect cellular reactions to NPs (Kim et al., 2014).

Although nanoparticles usage and application in different fields of life are developing rapidly; the full data about its health hazards and toxic effects are still unsatisfactory (Seok et al., 2013).

One of the most important fatsoluble vitamins is vitamin $\mathrm{E}$ which is primarily found in some plants. Vegetable oils are very rich in vitamin E (especially wheat germ, soybean and corn oils), margarine, nuts, seeds, cereal grains and vegetables (Srivastava and Gupta, 2016). Vitamin E contains eight naturally occurring isomers classified into two classes labeled as tocopherols and tocotrienols, but has altered biologic activities. Alpha-tocopherol has the highest biologic activity and it is the most available compound of vitamin $\mathrm{E}$ in food and commercially available vitamin $\mathrm{E}$ supplements. Vitamin $\mathrm{E}$ is an antioxidant which can hunt free radicals, which can start or propagate the oxidation of lipid chain by direct or indirect way (Pekiner, 2003).

\section{MATERIAL AND METHODS}

\section{- Materials:}

(1) Chemicals and Preparation

a. Zinc oxide nanoparticles $(\mathrm{ZnO}$ NPs):

Its molecular weight is about 81.39 $\mathrm{g} / \mathrm{mol}$ and $80 \% \mathrm{Zn}$ basis, CAS No. is 1314-13-2, manufactured by SigmaAldrisch chemical company, USA and obtained from Sigma-Egypt (Eltayaran st., Nasr city-Cairo).

\section{b. Vitamine E:}

It was obtained from Safe Pharma for Pharco Pharmaceuticals, Alexandria, Egypt.

\section{c. Corn Oil:}

It was obtained from Sekem, Cairo.

(2) Experimental Animals

The experiment was carried out on 36 adult male albino rats, with average 
weight between (150-200) gm, and average age of adult rat is about-50-60 days. We got them from the Animal House in Faculty of Medicine, Zagazig University. They were kept under hygienic conditions and fed on a balanced diet and water ad-libitum.

The study was conducted at the Animal House of Faculty of MedicineZagazig University, and performed in accordance with the guidance of ethical committee for research on laboratory animals.

\section{- Methods:}

\section{(1) Study design}

The rats were classified into 4 groups: Group I (control group) (18 rats) which was subdivided into 3 groups: Group IA (negative control group) (6 rats): fed on regular diet and water to determine the basic values of performed tests for 8 weeks. Group IB (vehicle control group) (6 rats): Rats were treated with $1 \mathrm{ml}$ deionized water once daily by oral gavage for 8 weeks. Group IC (vehicle control group) (6 rats): Rats were treated with $1 \mathrm{ml}$ corn oil once daily by oral gavage for 8 weeks. Group II (vit E treated group) (6 rats): These rats were gavaged orally with vitamin E (100mg / $\mathrm{kg}$ body weight) dissolved in corn oil. Group III (Zinc oxide NPs treated group) (6 rats): These rats were gavaged orally with a daily dose of Zinc oxide NPs $(422 \mathrm{mg} / \mathrm{kg})$ dissolved in $1 \mathrm{ml}$ deionized water and shaked by vortex for $15 \mathrm{~min}$. The dose represents $1 / 20$ of oral LD50 of Zinc oxide NPs in rats $(8437 \mathrm{mg} / \mathrm{kg})$ for 8 weeks. Group IV (Zinc oxide nanoparticles+ vitamin E treated group)(6 rats): Each rat was gavaged orally a daily dose of Zinc oxide NPs $(422 \mathrm{mg} / \mathrm{kg})$ then gavaged orally with vitamin E (100mg / kg body weight (Material Safety Data Sheet according to OSHA and ANS) (Wang et al., 2008).

(2) Sampling

After a period of 8 weeks (24 hours from the last dose) rats of all groups were exposed to;

i. Blood sample:

By using capillary glass tubes from the retro-orbital plexus as designated by Nemzek et al, (2001), and under ether anesthetic effect. Venous blood samples were gotten from each rat $(3 \mathrm{ml})$. The incubation of this blood took place at $37^{\circ} \mathrm{C}$ until clotting has occurred and then centrifuged to separate the serum.

The blood samples were used for assessing reduced glutathione (GSH) and Malondialdehyde (MDA) levels.

ii. Stomach and Pancreas samples:

The rats were sacrificed. The stomach and pancreas were dissected and examined as following:

For the microscopic histopathological examination stomach and pancreas specimens were fixed in $10 \%$ formalin.

(3) Oxidative stress markers

a. Estimation of reduced
glutathione (GSH) by 5,5'
dithiobis nitro benzoic acid assay (Moron et al., 1979):

The principle of the technique is a reaction between reduced GSH with 5, $5^{\prime}$ dithiobis nitro benzoic acid (DTNB) and the result will be a yellow color product. The $\mathrm{PH}$ of media in this reaction is 8.0 for 10 minutes.

Serum GSH content was gained from the absorbance on (Erba Chem 7) spectrophotometer at $412 \mathrm{~nm}$. 
b. Estimation of serum Malondialdehyde (MDA) by Thiobarbituric acid assay (Yoshioka et al., 1979):

The principle of the technique is a reaction between MDA with thiobarbituric acid (TBA) and yields trimethine complex. Its color is pink. The PH of media should be 2.3 at 90 $100^{\circ} \mathrm{c}$ for $10-15$ minutes.

Serum MDA content was gained from the absorbance on (Erba Chem 7) spectrophotometer at $532 \mathrm{~nm}$.

(4) Histopathological studies:

The stomach and pancreas were handled and sectioned at 4-5 $\mathrm{mm}$ thickness. The obtained tissue sections were fixed on glass slides, deparaffinized and we used Hematoxylin and Eosin for stainning. The organs slides were then studied and observed under a light microscope at magnifications X100 and X400 (Bancroft and Stevens, 1997).

(5) Detection of DNA fragmentation

Extraction kit (iNtron bio-tehnology, Seongnam-Si, Gyeonggi-do, Korea). Protocol used for DNA extraction from stomach and pancreas tissues was followed according to Buffone and Darlington, (1985).

Reagents:

Tris Acetate EDTA (TAE) buffer for electrophoresis, Ethidium bromide solution, Electrophoresis-grade agarose, loading dye, DNA molecular weight markers (ladder).

Sample loading:

Five $\mu l$ loading dye was added to each DNA sample. This allows to load gel wells more easily and to screen the run of

samples. The samples were immediately loaded to each well of a standard $1 \%$ agarose gel containing ethidium bromide $0.5 \mathrm{mg} / \mathrm{mL}$, appropriate DNA molecular weight markers was included.

The electrophoresis was run in TAE buffer. Electrophoresis was done 100 $\mathrm{mA}$ and 70 volts for about one hour using the EC 360 Submarine Gel electrophoresis system (Maxicell, EC 360 M-E-C apparatus Cooperation St. Petersburg. Florida, USA).

(6) Statistical analysis

Data collected throughout laboratory investigations and outcome measures coded. We used Microsoft Excel software to enter and analyze it. Data was then introduced into Statistical Package for the Social Sciences (SPSS version 20.0) (Statistical Package for the Social Sciences) software for analysis. According to the type of data, the following tests were used to test differences for significance; Differences between multiple means (quantitative variables) were compared by ANOVA test, Followed by LSD. P value was set at $<0.05$ for significant results, $<0.01$ for high significant result and $<0.001$ for very high significant result.

\section{RESULTS}

\section{(1) Oxidative stress markers:}

\section{a) Serum Glutathione}

As comparing the serum level results of reduced glutathione $(\mathrm{nmol} / \mathrm{l})$ of the negative control group I (A), vehicle control group I (B), vehicle control group I (C) and vitamin $\mathrm{E}$ treated group II there was no statistically significant difference between them ( $p>0.05)$ (Table: 1) So the results of the negative control group (IA) were used for comparison with those of treated groups. 
The reduced glutathione level mean values of Zinc oxide nanoparticles treated group III showed a significant decrease $(\mathrm{p}<0.05)$ compared to control group IA. There was a non-significant difference $\quad(p>0.05)$ in reduced glutathione level mean values of Zinc oxide nanoparticles \& vitamin $\mathrm{E}$ treated group IV compared with control group IA. At the same time there was a significant increase $(p<0.05)$ in reduced glutathione level mean values of Zinc oxide nanoparticles \& vitamin E treated group IV compared with those of zinc oxide nanoparticles treated group III (Table: 2).

\section{b) Serum malondialdehyde $\underline{(M D A)}$}

As comparing the serum level results of malondialdehyde $(\mathrm{nmol} / \mathrm{l})$ of the negative control group I (A), vehicle control group I (B), the vehicle control group I (C) and vitamin $\mathrm{E}$ treated group II there was no statistically significant difference between them ( $>0.05)$ ) (Table:1).

So the results of the negative control group (IA) were used for comparison with those of treated groups.

Malondialdehyde level mean values of Zinc oxide nanoparticles treated group III showed a significant increase $(\mathrm{p}<0.05)$ compared to control group IA. There was a non-significant difference $(p>0.05)$ in malondialdehyde level mean values of Zinc oxide nanoparticles \& vitamin $\mathrm{E}$ treated group IV compared with control group. At the same time there was a significant decrease $(p<0.05)$ in malondialdehyde level mean values of Zinc oxide nanoparticles \& vitamin E treated group IV compared with those of zinc oxide nanoparticles treated group III (Table: 2). 
Table (1): Statistical comparison between mean values of serum reduced glutathione and malondialdehyde (nmol/l) in control group1 (1a, 1b\&1c) and vitamin $\mathrm{E}$ treated group II after 8 weeks of treatment using ANOVA (analysis of variance) test:

\begin{tabular}{|c|c|c|c|c|c|c|}
\hline $\begin{array}{c}\begin{array}{c}\text { Group } \\
(\mathrm{n}=6)\end{array} \\
\text { Variable }\end{array}$ & $\begin{array}{c}\text { Control } \\
\text { Group Ia }\end{array}$ & $\begin{array}{c}\text { Control } \\
\text { Group Ib }\end{array}$ & $\begin{array}{c}\text { Control } \\
\text { Group Ic }\end{array}$ & $\begin{array}{c}\text { Vitamin E } \\
\text { treated } \\
\text { group } \\
\text { Group II }\end{array}$ & $\mathbf{F}$ & $\mathbf{p}$ \\
\hline $\begin{array}{l}\text { Reduced } \\
\text { glutathione: } \\
\text { (nmol/l) } \\
\text { Mean } \pm S D\end{array}$ & $48.9 \pm 4.1$ & $48 \pm 0.84$ & $47.08 \pm 1.27$ & $47.5 \pm 0.9$ & 0.738 & $\begin{array}{c}0.542 \\
\text { NS }\end{array}$ \\
\hline $\begin{array}{l}\text { Malondialde } \\
\text { hyde: } \\
\text { (nmol/l) } \\
\text { Mean } \pm S D\end{array}$ & $75.5 \pm 3.8$ & $76.6 \pm 1.07$ & $76.1 \pm 0.84$ & $76.3 \pm 1.4$ & 0.284 & $\begin{array}{c}0.836 \\
\text { NS }\end{array}$ \\
\hline
\end{tabular}

$\mathrm{NS}=$ non significant

Table (2): Statistical comparison between mean values of serum reduced glutathione and malonaldehyde (nmol/l) in group Ia (control), group III (Zinc oxide nanoparticles) and group IV (Zinc oxide nanoparticles \& Vit E) after 8 weeks of treatment using ANOVA (analysis of variance) test:

\begin{tabular}{|c|c|c|c|c|c|}
\hline $\begin{array}{l}\text { Group }(n=6) \\
\text { Variable }\end{array}$ & $\begin{array}{c}\text { Group Ia } \\
\text { (control } \\
\text { group) }\end{array}$ & $\begin{array}{c}\text { Group III } \\
\text { (Zinc oxide } \\
\text { nanoparticles } \\
\text { treated } \\
\text { group) }\end{array}$ & $\begin{array}{c}\text { Group IV } \\
\text { (Zinc oxide } \\
\text { nanoparticle } \\
\text { s + Vit E } \\
\text { treated } \\
\text { group) }\end{array}$ & $\mathbf{F}$ & $\mathbf{p}$ \\
\hline 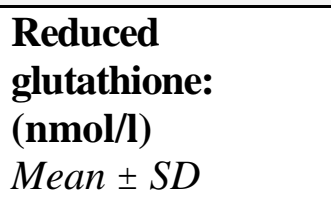 & $48.9 \pm 4.1^{b}$ & $33.8 \pm 2.4^{\mathrm{ac}}$ & $50.4 \pm 4.2^{b}$ & 37.738 & $0.000 *$ \\
\hline $\begin{array}{l}\text { Malondialdehyde: } \\
\text { (nmol/l) } \\
\text { Mean } \pm S D\end{array}$ & $75.5 \pm 3.8^{b}$ & $125.1 \pm 9.8^{\mathrm{ac}}$ & $80.9 \pm 5.1^{b}$ & 97.654 & $0.000 *$ \\
\hline
\end{tabular}

n: Number of rats in each group. SD: Standard Deviation. *: highly significant $(<0.001)$. $\mathbf{n m o l} / \mathbf{l}=$ nanomol per liter 
(2) Histopathological results (Light microscopic examination of $\mathrm{H \& E}$ stained sections):

\section{a) Stomach}

\section{Grouop I, II:}

The microscopic examination of $\mathrm{H} \& \mathrm{E}$ stained sections of the stomach of the control group and vitamin E treated group showed normal gastric mucosal structures (Fig 1).

Group III (Zinc oxide nanoparticles treated group): The stomach showed dense submucosal inflammatory cell infiltration, and numerous eosinophyllic chief cells infiltration (Fig 2).

Group IV (Zinc oxide nanoparticles and vitamin $\mathrm{E}$ treated group):

The stomach showed submucosal edema and moderate inflammatory cell infiltration. Submucosal congestion. Scattered intracytoplasmic hyaline droplets (Fig 3).

b) Pancreatic cells:

\section{Group I, II:}

The Pancreas of control group and vitamin $\mathrm{E}$ treated group showed normal structure of pancreatic cells (Fig 4).

Group III (Zinc oxide nanoparticles treated group):

The Pancreas showed ductular hyperplasia and numerous acinar apoptosis (Fig 5).

Group IV (Zinc oxide nanoparticles and vitamin E treated group):

The pancreas demonstrated mild interstitial inflammatory cell infiltration associated with ductular hyperplasia (Fig 6).
(3) DNA fragmentation test results: In stomach and pancreatic cells of control group, the DNA was not fragmented, whereas the cells of group III treated with $\mathrm{ZnO} \mathrm{Nps}$ had ongoing the process of apoptosis, as was evident with DNA fragmentation. While in cells of group IV treated with vitamin $\mathrm{E}+$ $\mathrm{ZnO} \mathrm{Nps}$, vitamin E suppress apoptosis and DNA was not fragmented (Fig 7). 


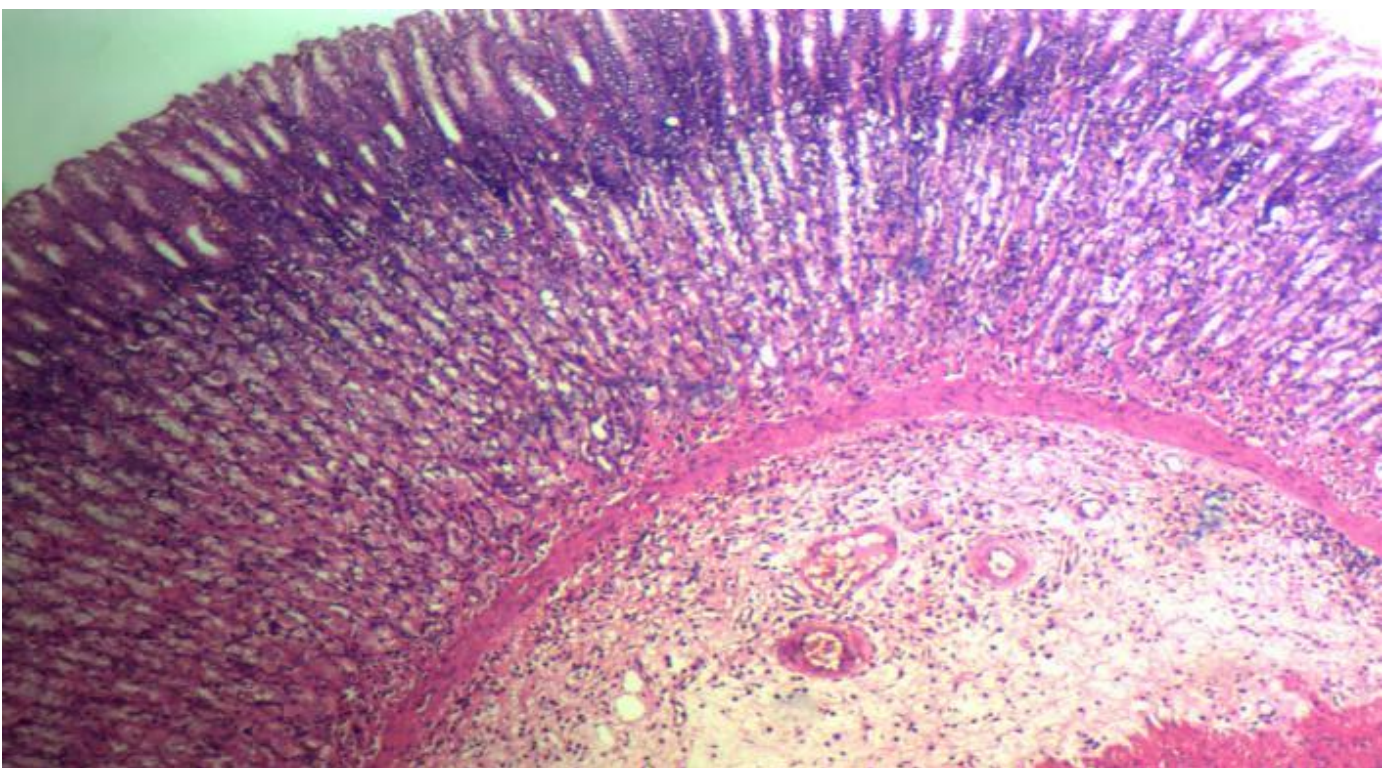

Figure (1): Histopathological features of rat stomach: Section from control group showing normal histology of gastric mucosa (H\&Ex400).

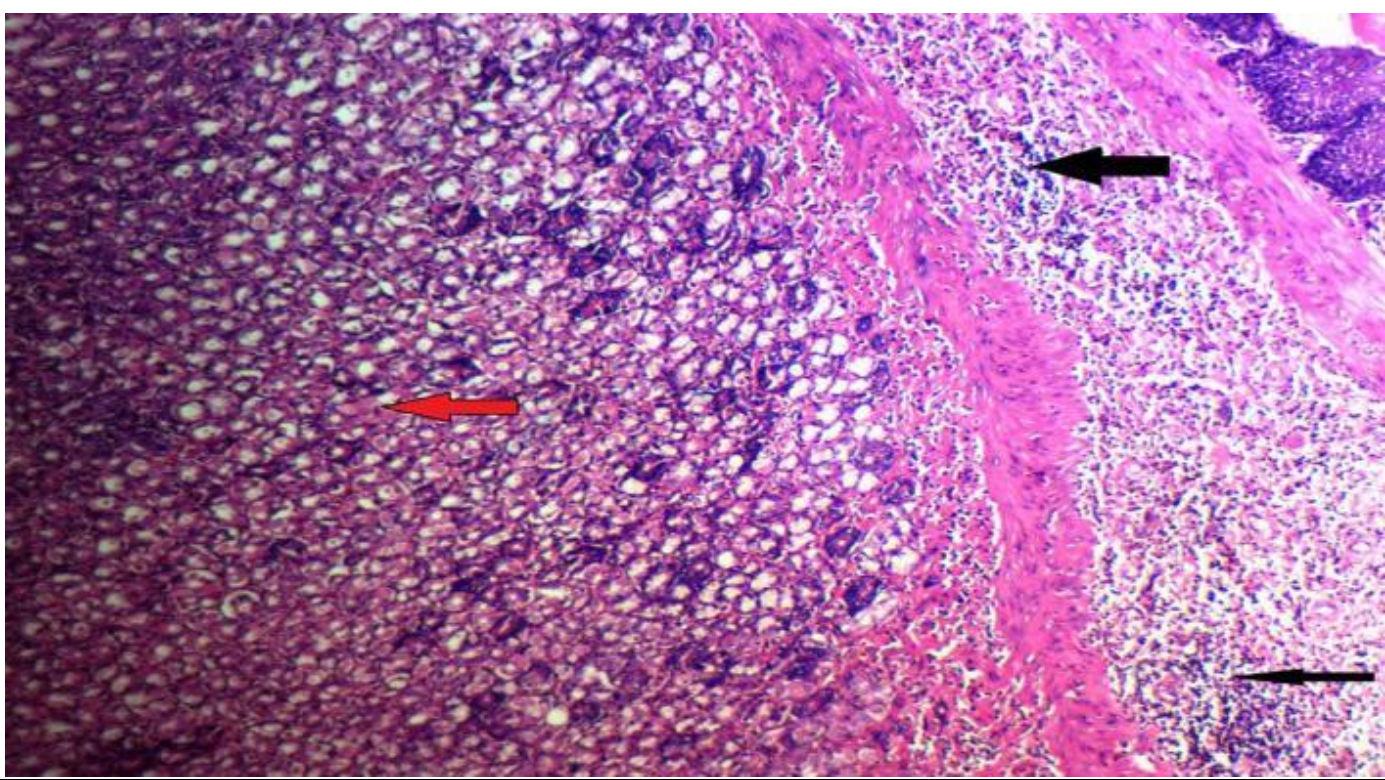

Figure (2): Histopathological features of rat stomach: Section from zinc oxide nanoparticles treated group showing Heavy submucosal inflammatory cell infiltrate (black arrows), and mild esniophillic chief cells (red arrow) (H\&Ex200). 


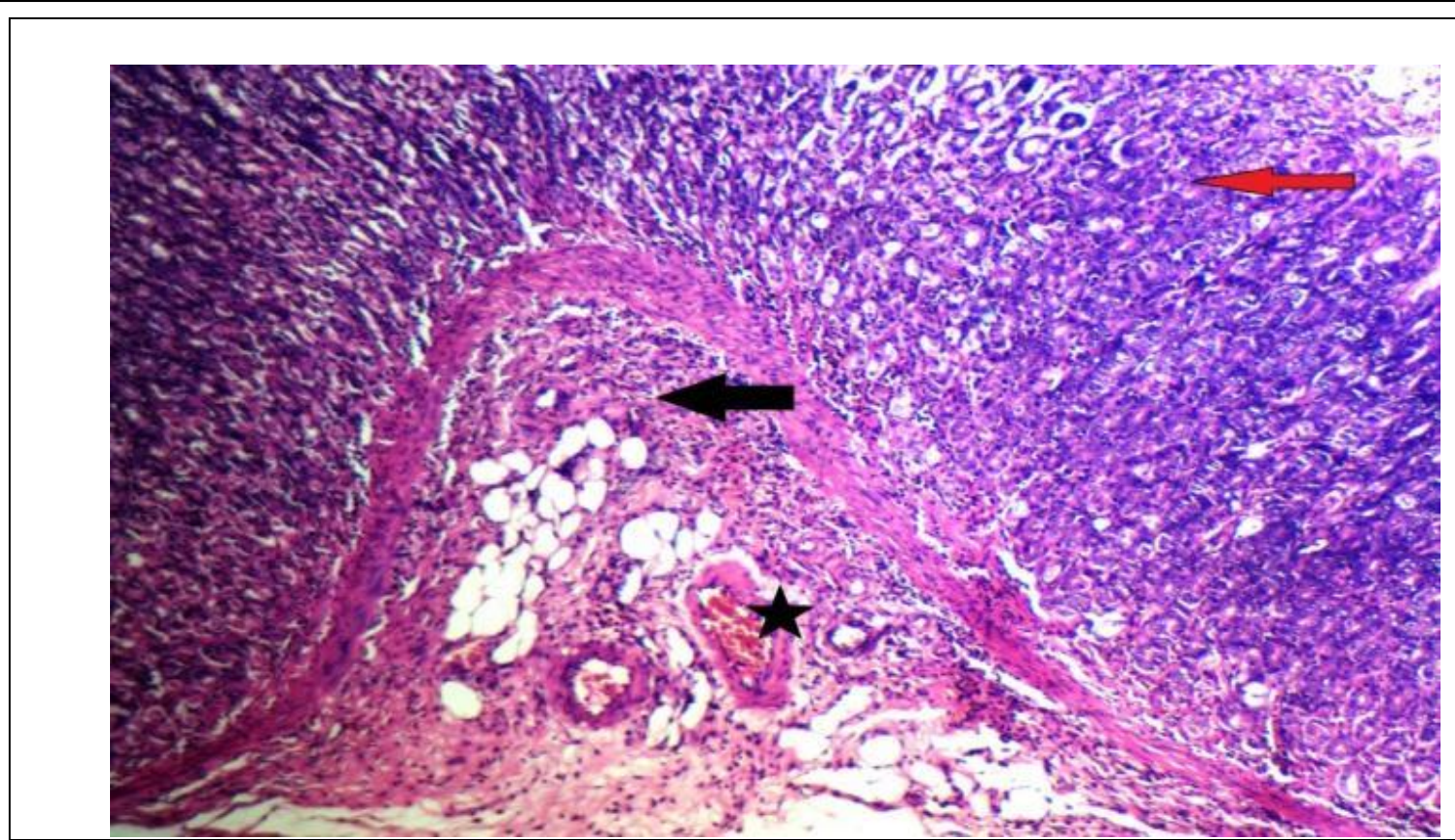

Figure (3): Histopathological features of rat stomach: Section from zinc oxide nanoparticles + vit $E$ treated group showing Sbmucosal edema and moderate inflammatory cell infiltrate (black arrow). Submucosal congestion (star), and Scattered intracytoplamic hyaline droplets (red arrow) (H\&Ex200).

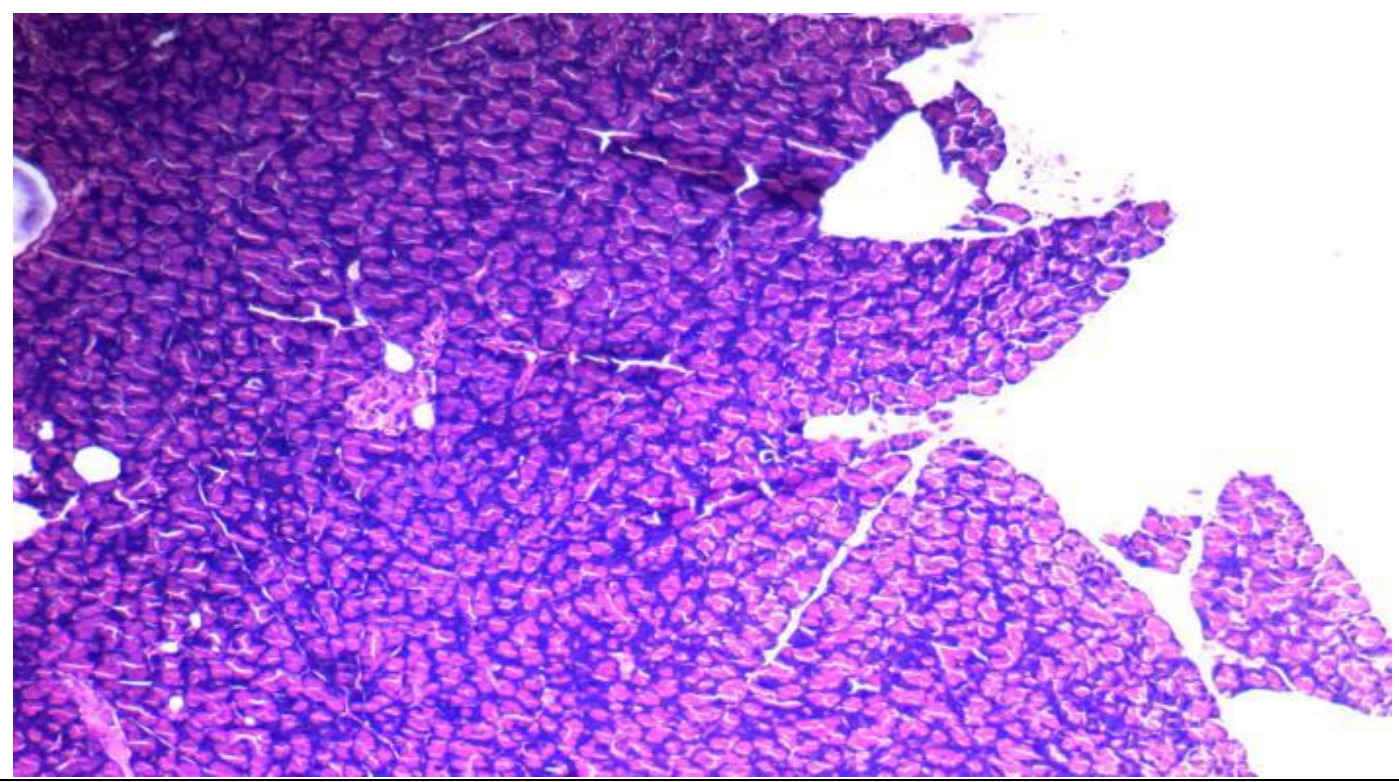

Figure (4): Histopathological features of rat pancreatic cells: Section from control group showing normal pancreatic cells $(\mathbf{H} \& \mathbf{E x 2 0 0})$ 


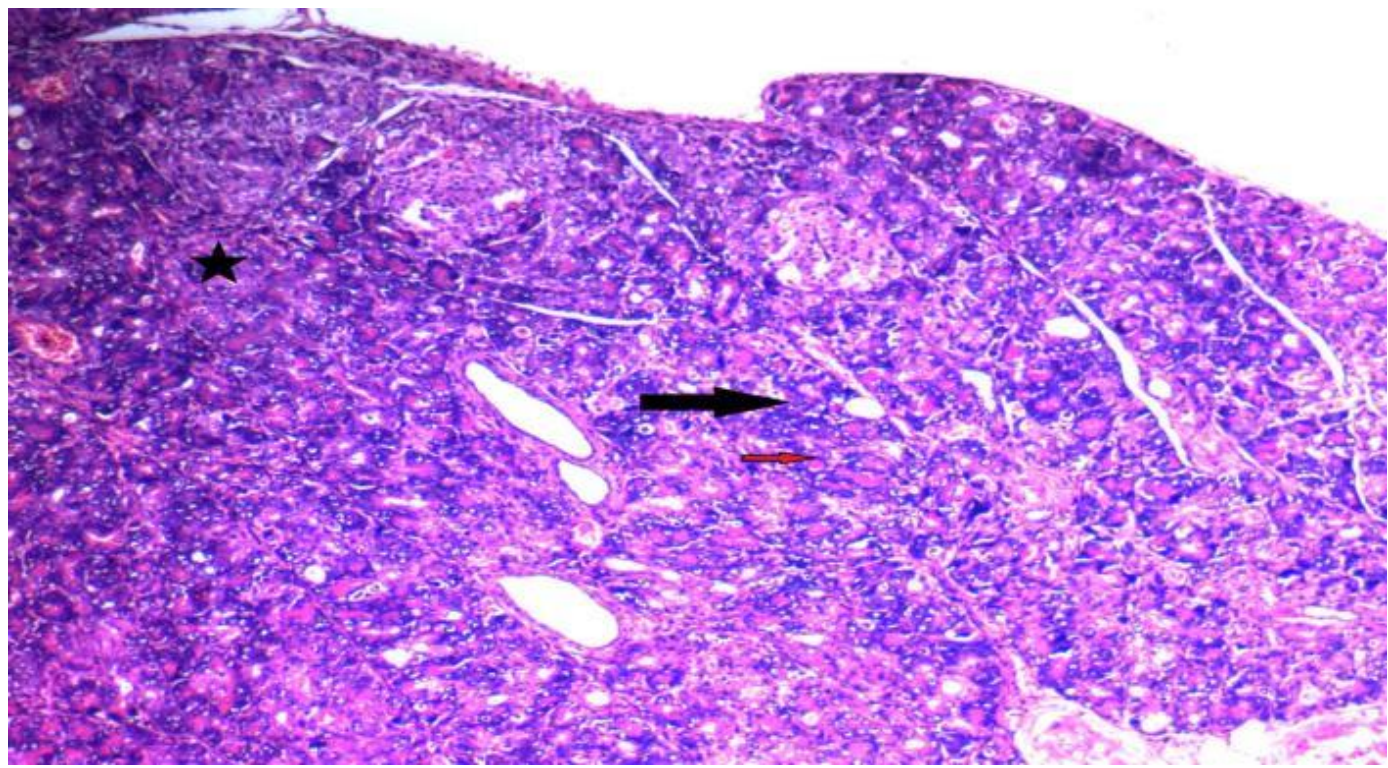

Figure (5): Histopathological features of rat pancreatic cells: Section from zinc oxide treated group showing interstitial inflammatory cell infiltrate (black arrow), Ductular hyperplasia (star) and some scattred apoptotic bodies (red arrow) (H\&Ex200).

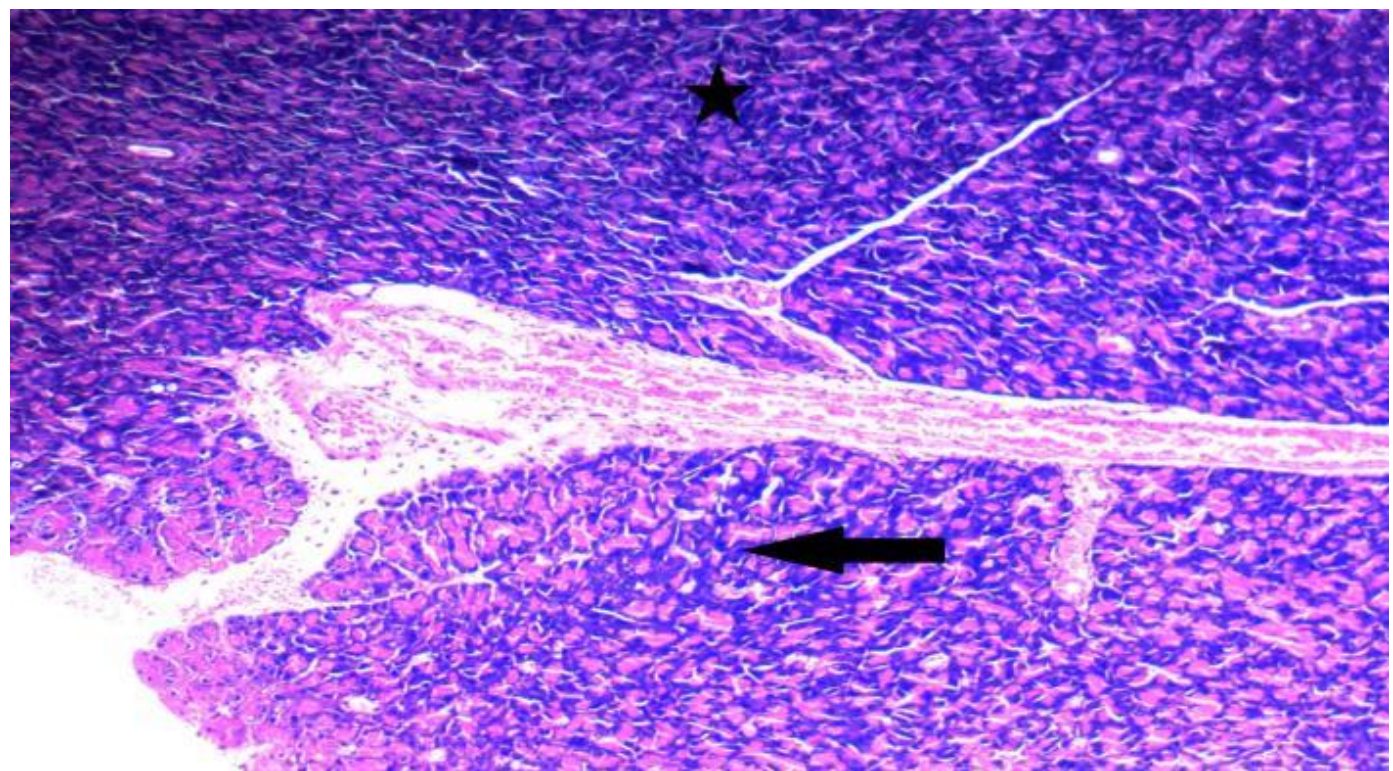

Figure (6): Histopathological features of rat pancreatic cells: Section from zinc oxide + vit $\mathbf{E}$ treated group showing Mild interstitial inflammatory cell infiltrate (black arrow) associated with ductular hyperplasia (star) (H\&Ex200). 


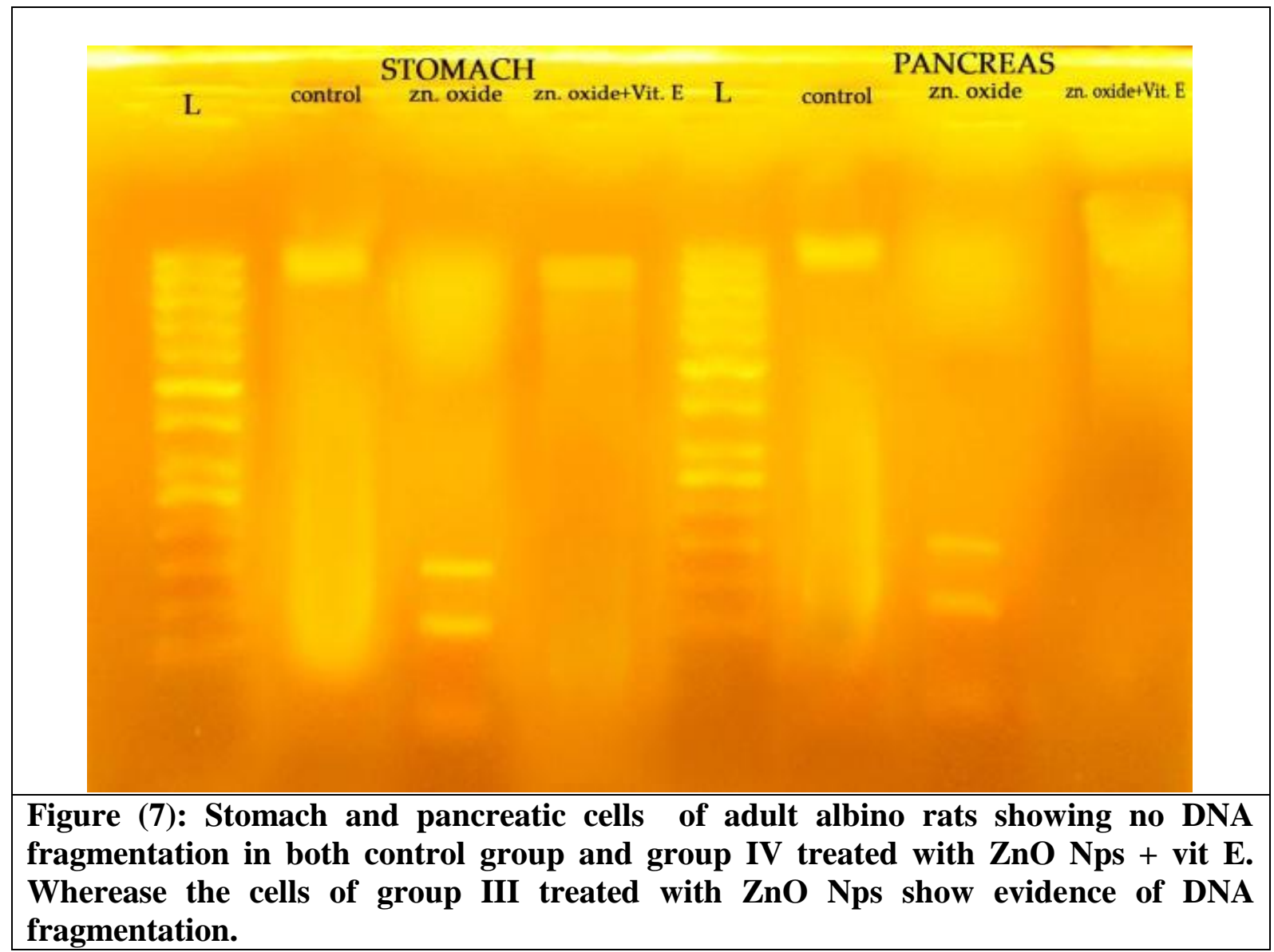
fragmentation.

\section{DISCUSSION}

Nanotoxicology is a study which focuses on how nanomaterials may affect cellular function and their toxicity degree. Usually $\mathrm{ZnO}$ NPs accumulate in the environment and food chain and continuous exposure to them may have an adverse impact on human health (AlSuhaibani and El-Morshedi, 2014).

Demir et al., (2014), revealed that ROS extensively induced after exposure to $\mathrm{ZnO}$ nanomaterials, based on both material structure and surface features, while other nanomaterials generate ROS only in the existence of particular cell systems.

Elevated ROS production that exceeds the ability of the cellular antioxidant defense system (One of the mechanisms of cellular toxicity) cause oxidative stress to cells. This result in destruction of cellular structures such as lipids, proteins, and DNA (Scherzad et al., 2017).

Also lipid peroxides can results from fatty acids oxidation which start a chain reaction. Plasma disturbance, organelle membranes disruption and cell death are the end results of this chain reaction (Sharma et al., 2012).

In the present study, concerning microscopic examination of stomach sections, our results are similar to the results of Kim et al., (2014) who worked on $\mathrm{ZnO} \mathrm{Nps}$ and its effect on stomach and pancreas. They noticed hyperplasia of squamous cell lining the stomach and vacuolation of non-glandular stomach. Also, they mentioned the presence of hyaline droplets in cytoplasm, edema, 
inflammatory and eosinophilic cells in mucosa, and mucous cell hyperplasia in glandular stomach. Both apoptosis in acinar cell and chronic inflammation are found in the pancreatic cells.

Parallel to our results, the results of acute toxicity study of Wang et al., (2008), who study the toxic effect of $\mathrm{ZnO}$ NPs on stomach after oral doses administration, the experiment result was slight damages in stomach of rats. Another study was done for 14 days; the animals were exposed to $20 \mathrm{~nm} \mathrm{ZnO}$ NPs daily which induced marked inflammation of both stomach and pancreas. The pancreas showed apoptosis in acinar cell.

Concerning

microscopic

examination of pancreas sections, our results are almost in agree with those of a study by Seok et al. (2013), showed moderate pancreatitis with focal lymphocytic infiltration and mild acinar cell apoptosis after administration of $536.8 \mathrm{mg} / \mathrm{kg} 1 \mathrm{ZnO} \mathrm{NP}$.

By inhibiting lipid peroxidation, vitamin $\mathrm{E}$ maintains the integrity, function and flexibility of cell membranes. Also vitamin $\mathrm{E}$ plays an important role in reducing inflammation (AL-Rasheed et al., 2016).

Concerning oxidative stress

markers, results of the present study agree with results of Kononenko et al. (2017), where a decrease in GSH activity was observed in rats treated with $\mathrm{ZnO}$ NPs, representing the potential impairment of cellular stress-defense capacity.

$\mathrm{ZnO}$ NPs related glutathione decreased level might be due to over production of ROS, particularly $\mathrm{O} 2$. Autocatalysis of oxidative damage process depends on the following; presence of free radicals, elevated enzyme inactivation and the last is decreased the enzymatic activities (Ali et al., 2012).

AL-Rasheed et al. (2016) proved that the intake of vitamin $\mathrm{E}$ along with $\mathrm{ZnO}$ NPs ingestion markedly increased GSH level which was decreased in a $\mathrm{ZnO}-\mathrm{NPs}$ administered group. Vitamin E played a major role in cleansing the body of free radicals. It performed its function as an antioxidant in the glutathione peroxidase pathway.

Regarding DNA fragmentation, the present study revealed genotoxic effect evident by DNA fragmentation in group III treated with ZnO NPs. While, DNA was not fragmented in group IV treated with vitamin $E$.

Premanathan et al., (2011), reported that the cytotoxicity induced as a result of zinc oxide nanoparticles effect originating from an apoptotic pathway. DNA fragmentation was the first step in the process of apoptosis initiated by $\mathrm{Zn}$ O. The primary mechanism of cytotoxicity initiated with ROS overproduction, which then were accountable for the initiation of apoptosis.

\section{CONCLUSIONS}

From the previous results of the current study it has been determined that the Zinc oxide nanoparticles harmfully upset body systems through their oxidative stress effects, and afterwards the liberation of reactive oxygen species. Also, they have genotoxic effect evident by DNA fragmentation. Supplementation of vitamin $\mathrm{E}$ during Zinc oxide nanoparticles exposure may have protective effects against stomach and pancreas dysfunction. 


\section{RECOMMENDATIONS}

The results of present study may increase the alarms about the probable risk on human health that might be related with plentiful applications of $\mathrm{ZnO}$ NPs. More effort is needed to clarify the prospective threats of these particles on the different organs and their pathogenesis. Using vitamin $\mathrm{E}$ as an important anti-oxidant may help a lot to modify the harmful effects of ZnO NPs.

\section{REFERENCES}

Ali D., Alarifi S., Kumar S., Ahamed M. and Siddiqui M. (2012): Oxidative stress and genotoxic effect of zinc oxide nanoparticles in freshwater snail Lymnaea luteola L. Aquatic Toxicology 124: 83- 90.

Almansour M., Alferah M., Shraideh Z. and Jarrar B. (2017): Zinc oxide nanoparticles hepatotoxicity: Histological and histochemical study. Environmental Toxicology and Pharmacology. 2721:1-7.

\section{AL-Rasheed N., Ali H. and Abdelbaky}

N. (2016): Modulation of glutathione, phospholipids and lipid peroxides liver contents induced by zinc oxide nanoparticles using natural antioxidants. 11(1): 303-312.

\section{Al-Suhaibani E. and El-Morshedi N.} (2014): Histopathological and Ultrastructural Effect of Zinc Oxide Nanoparticles on Male Wistar Rats Submandibular Glands. IOSR Journal of Pharmacy and Biological Sciences. 9:05-09.
Bancroft and Stevens (1997): Theory and practice of histological techniques. The journal of pathology. 183(2): 243-244.

Buffone G. and Darlington G. (1985): Growth and hepatospecific gene expression of human hepatoma cells in a defined medium. In Vitro Cellular \& Developmental Biology. 23: 349-354.

Chang Y., Zhang M., Xia L., Zhang J. and Xing G. (2012): The Toxic Effects and Mechanisms of $\mathrm{CuO}$ and $\mathrm{ZnO}$ Nanoparticles. Materials. 5: 2850-2871.

Demir E., Akc H., Kaya B., Burgucu D., Tokgün O., Turna F., et al., (2014): Zinc oxide nanoparticles: Genotoxicity, interactions with UV-light andcell-transforming potential. Journal of Hazardous Materials. 264:420- 429.

Esmaeillou M., Moharamnejada M., Hsankhania R., Tehranic A. and Maadi H. (2013): Toxicity of $\mathrm{ZnO}$ nanoparticles in healthy adult mice. Environmental toxicology and pharmacology. 35: 67-71.

Jeong S., Kim H., Ryu H., Ryu W., Park Y., Bae H. et al., (2013): $\mathrm{ZnO}$ nanoparticles induce TNF-a expression via ROS-ERK-Egr-1 pathway in human keratinocytes. Journal of Dermatological Science. 72: 263-273.

Kim Y., Park J., Lee E., Park S., Seong N. and Kim J. (2014): Toxicity of $100 \mathrm{~nm}$ zinc oxide 
nanoparticles: a report of 90-day repeated oral administration in Sprague Dawley rats. International Journal of Nanomedicine. 9:109-126.

\section{Kononenko V., Repar N., Marusic N.,} Drasler B., Romih T., Hocevar S. et al. (2017): Comparative in vitro genotoxicity study of $\mathrm{ZnO}$ nanoparticles, $\mathrm{ZnO}$ macroparticles and $\mathrm{ZnCl} 2$ to MDCK kidney cells: Size matters. Toxicology in Vitro. 40: 256-263.

\section{Lanone S1, and Boczkowski J. (2006):} Biomedical applications and potential health risks of nanomaterials: molecular mechanisms.6 (6):651-663.

Moron M.S., Depierre J.N. and Manervik V. (1979): Levels of glutathione, glutathione reductase and glutathione-s-transferase activities in rat lung and liver. Biochimica et. Biophysica Acta. 582:67-68.

\section{Nemzek J, Bolgos G, Williams, B et al} (2001): Differences in normal values for murine white blood cell counts and other hematological parameters based on sampling site. Inflammation Research. 50: 523-527.

Pekiner B. (2003): Vitamin E as an antioxidant. Ankara Ecz.Fak.Derg. J. Fac. Pharm. 32 (4): 243-267.
Premanathan M., Karthikeyan K., Jeyasubramanian $K$. and Manivannan G. (2011): Selective toxicity of $\mathrm{ZnO}$ nanoparticles toward Gram-positive bacteria and cancer cells by apoptosis through lipid peroxidation. Nanomedicine: Nanotechnology, Biology, and Medicine 7:184-192.

Rasmussen J., Martinez E., Louka P. and Wingett D. (2010): Zinc Oxide Nanoparticles for Selective Destruction of Tumor Cells and Potential for Drug Delivery Applications. 7(9): 1063-1077.

\section{Scherzad A., Meyer T., Kleinsasser N.} and Hackenberg S. (2017): Molecular Mechanisms of Zinc Oxide Nanoparticle-Induced Genotoxicity Short Running. Title: Genotoxicity of $\mathrm{ZnO}$ NPs. Materials. 10: 1427- 1446.

Seok S., Cho W., Park J., Na Y., Jang A., Kim H. et al., (2013): Rat pancreatitis produced by 13 -week administration of zinc oxide nanoparticles: biopersistence of nanoparticles and possible solutions. Journal of applied Toxicology. 10:1002-1020.

Sharma V., Anderson D. and Dhawan A. (2012): Zinc oxide nanoparticles induce oxidative DNA damage and ROS-triggered mitochondria mediated apoptosis in human liver cells (HepG2). Apoptosis. 17:852-870.

Srivastava S. and Gupta P. (2016): Genotoxic and Infertility Effects 
of Bisphenol A on Wistar Albino rats. Int. J. Pharm. Sci. Rev. Res. 41(1):126-131.

Wang B., Feng W., Wang M. et al. (2008): Acute toxicological impact of nano- and submicroscaled zinc oxide powder on healthy adult mice. $J$ of Nanoparticles Res. 10:263-276.

Yoshioka T., Kwada K., Shimada T. and Mori M. (1979): Lipid peroxidation in maternal and cord blood and protective mechanisms against elevated oxygen toxicity in the blood. American journal of obstetrics and gynecology. 135:972-976. 
دراسة الآثار السمّية الجينية شبه المزمنة للجزيئات دقيقة الحجم لأكسيد الزنك و الدور الوقائي لفيتامين (ه) على المعدة و البنكرياس في الجرذان البيضاء البالغة

المقدمة: تستخدم الجزيئات دقيقة الحجم في نطاق واسع في عديد من المجالات المختلفة مثل مستحضرات التجميل ، وتصنيع الملابس ،

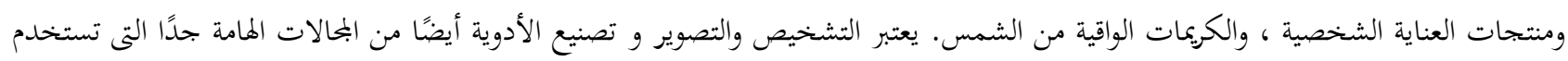

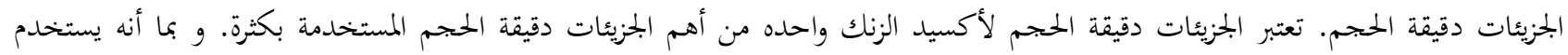

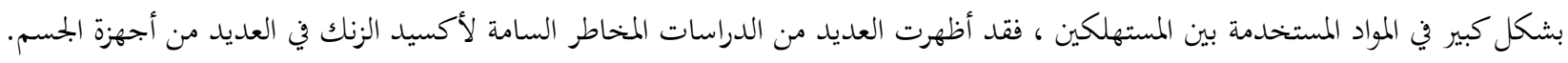

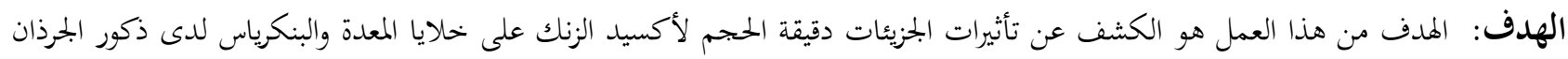

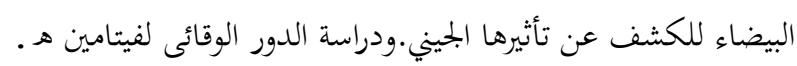

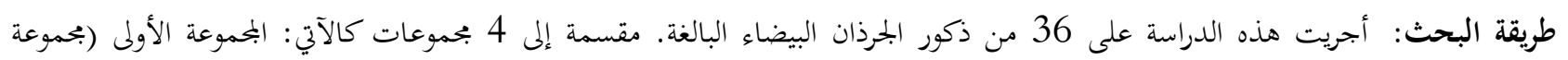

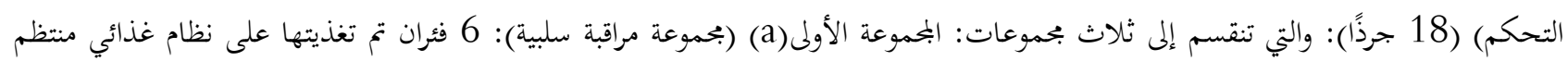

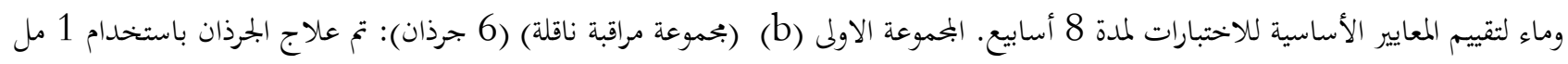

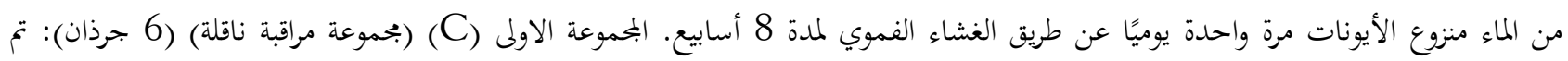

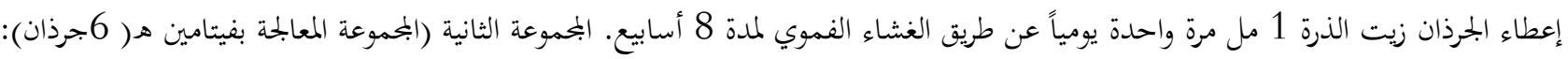

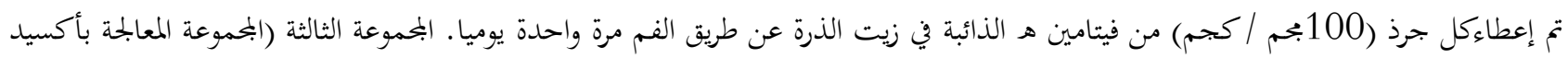

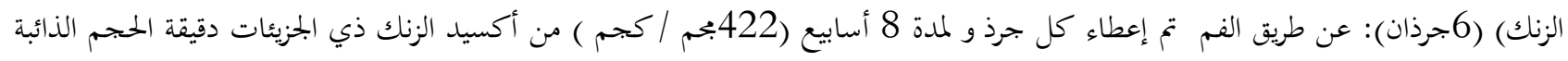

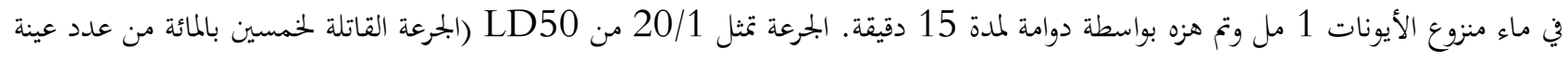

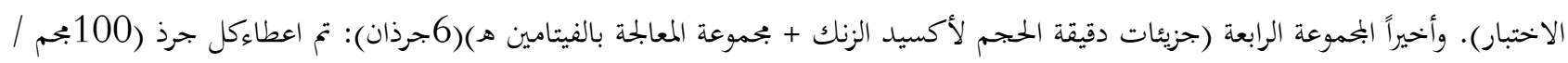

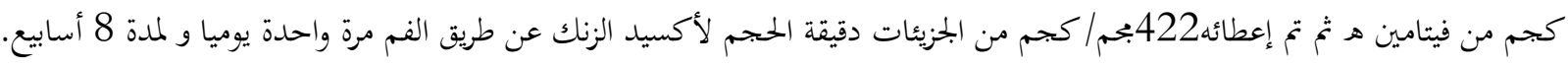

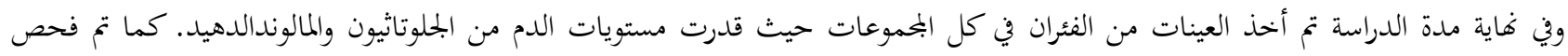

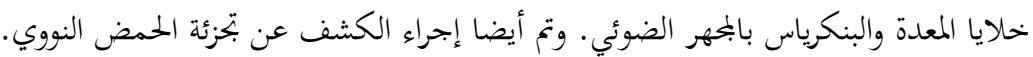

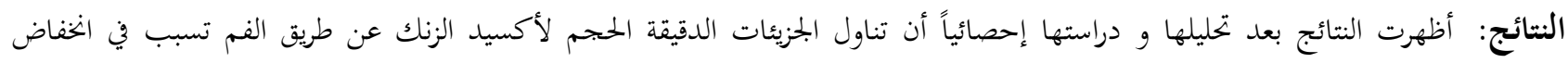

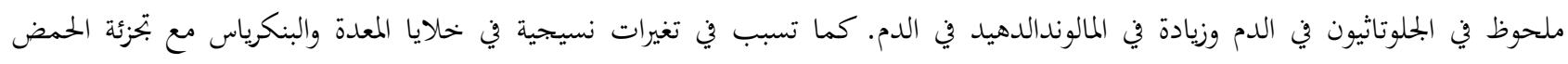

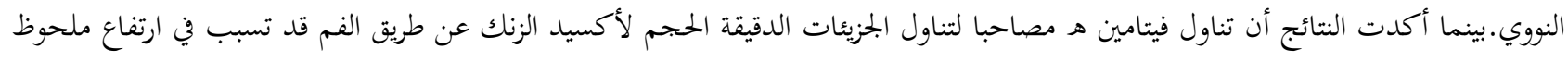

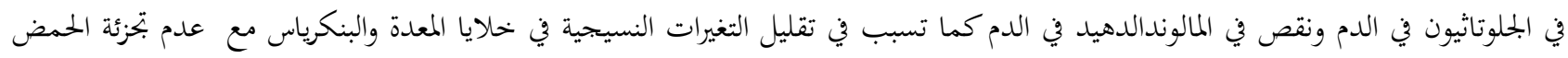
النووي.

الخحلاصة: وقد خلصت الدراسة إلى أن تناول الجزيئات دقيقة الحجم لأكسيد الزنك عن طريق الفم قد أحدث تأثيرات تدميرية جينية في خلايا

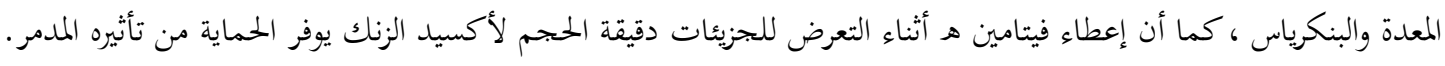

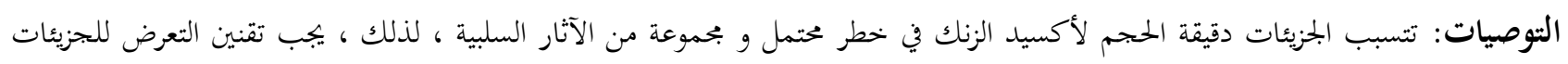
دقيقة الحجم لأكسيد الزنك إما مهنيا أو فن الغذاء. أيضا ، رفع مستوى الوعي بين السكان حول آثاره الخطرة. وتوعيتهم بضرورة استخدام فيتامين هـ كعامل حماية من الآثار السلبية. 